\title{
Elaboration and Characterization of Glasses and Ceramic-Glasses within Theternary Diagram $\mathrm{Li}_{2} \mathrm{O}-\mathrm{Cr}_{2} \mathrm{O}_{3}-\mathrm{P}_{2} \mathrm{O}_{5}$
}

\author{
Said Aqdim ${ }^{1,2}{ }^{*}$, Yassine Er-rouissi ${ }^{1}$, Abdelmjid Cherif ${ }^{1}$, Radouane Makhlouk ${ }^{1}$ \\ ${ }^{1}$ Laboratoire de Génie des Matériaux pour Environnement et Valorisation, Département de Chimie, Faculté des Sciences, \\ Université Hassan II Ain Chock, Casablanca, Morocco \\ ${ }^{2}$ Laboratoire de Chimie Minérale, Département de Chimie, Faculté des Sciences, Université Hassan II Ain Chock, Casablanca, \\ Morocco \\ Email: *said_aq@yahoo.fr
}

How to cite this paper: Aqdim, S., Errouissi, Y., Cherif, A. and Makhlouk, R. (2017) Elaboration and Characterization of Glasses and Ceramic-Glasses within Theternary Diagram $\mathrm{Li}_{2} \mathrm{O}-\mathrm{Cr}_{2} \mathrm{O}_{3}-\mathrm{P}_{2} \mathrm{O}_{5}$. Advances in Materials Physics and Chemistry, 7, 123-137.

https://doi.org/10.4236/ampc.2017.74011

Received: February 27, 2017

Accepted: April 27, 2017

Published: April 30, 2017

Copyright (C) 2017 by authors and Scientific Research Publishing Inc. This work is licensed under the Creative Commons Attribution-NonCommercial International License (CC BY-NC 4.0).

http://creativecommons.org/licenses/by-nc/4.0/

\begin{abstract}
Use of the regular melting-quench method allowed the isolation of a small glass domain within the ternary system $\mathrm{Li}_{2} \mathrm{O}-\mathrm{P}_{2} \mathrm{O}_{5}-\mathrm{Cr}_{2} \mathrm{O}_{3}$ at $1000^{\circ} \mathrm{C}$. Electrical conductivity and dielectric permittivity measures on sample glasses and ceramic glasses of this domain were performed at a frequency of $10 \mathrm{kHz}$ and at temperatures between $25^{\circ} \mathrm{C}$ and $300^{\circ} \mathrm{C}$. The values of dielectric permittivity and electrical conductivity increase with increasing $\mathrm{Li}_{2} \mathrm{O}$ content. However, increases of $\mathrm{Cr}_{2} \mathrm{O}_{3}$ content, even at low concentrations, induce a change in electrical conductivity behaviour from that of a glass to that of a ceramic glass. The introduction of an increasing amount of $\mathrm{Li}_{2} \mathrm{O}$ content in vitreous phosphorus pentoxide changes its three-dimensional network; rupture of the $\mathrm{P}-\mathrm{O}-\mathrm{P}$ bond then occurs and there is formation of easily polarisable entities with quite high values of $\varepsilon_{r}^{\prime}$. The vibrational spectroscopy technique I.R has allowed an efficient investigation of the structural change versus composition within the above indicated ternary diagram. The maximal dielectric permittivity obtained at $300^{\circ} \mathrm{C}$, both for the glasses and for the ceramic glasses varied in the order $10^{4}$ to $3 \times 10^{5}$, while the maximum electrical conductivity obtained at $300^{\circ} \mathrm{C}$ for the ceramic glasses was in the order of $10^{-3} \Omega \mathrm{cm}^{-1}$.
\end{abstract}

\section{Keywords}

Phosphate Glasses, Glass Formation, XRD, IR Spectroscopy,

Electrical Conductivity, Dielectric Permittivity

\section{Introduction}

Several fundamental studies have been made on glasses composed of silica and 
with oxides of phosphoric anhydrides [1] [2] [3] [4]. Due to their low chemical durability, phosphate glasses have gained less attention. However, several phosphate glasses with high aqueous corrosion resistance have been reported [5][12]. The electrical engineering field constitutes one of the numerous fields of application of glasses. This field is particularly interested in materials with high ionic conductivity that can be used as solid electrolytes, or in materials of very high resistivity capable of playing the dielectric role for miniaturised condensers. Historically, ionic conduction has been studied in crystalline compounds for a long time [13]. The interest in ion-conducting glasses is more recent, but has progressed rapidly over the last thirty years due to the use of these materials as solid electrolytes. The transport properties of these electrolytes have been the subject of numerous works, whose main lines have been grouped together in some publications [14] [15] [16] [17]. The notion of point defects is a very useful tool in the interpretation of conduction in crystallised materials, but it is ill-defined for amorphous materials, because they do not have long-range structural periodicity. However, glasses have many spaces (due to their low density), which are capable of containing cations of different sizes [7] [16] [18] [19]. Ions that are weakly bonded to the network can move in the material under the action of a force resulting from an electric potential gradient. The well-known mobility of alkaline cations, and in particular $\mathrm{Li}^{+}$and $\mathrm{Na}^{+}$, in solid electrolytes has prompted us to explore the electrical conductivity of the revealed vitreous phases [2] [3] [4] [5]. Our aim in the present work is to define the glass area in the ternary system $\mathrm{Li}_{2} \mathrm{O}-\mathrm{P}_{2} \mathrm{O}_{5}-\mathrm{Cr}_{2} \mathrm{O}_{3}$ for the first time. A second aim is to undertake an electrical study of glasses and glass ceramics of the ternary system $\mathrm{Li}_{2} \mathrm{O}-\mathrm{P}_{2} \mathrm{O}_{5}-$ $\mathrm{Cr}_{2} \mathrm{O}_{3}$. The study of the conduction mechanisms and their relation to the structure of the phosphorus network illustrate that with increased amounts of the modifier oxide $\mathrm{Li}_{2} \mathrm{O}$ in the glass network, the mobility of the $\mathrm{Li}^{+}$carriers is facilitated, due to increased depolymerisation of the phosphate network [7] [18] [19]. On the other hand, the increasing glassy depolymerisation of the network induces an increase in the number of non-bridge oxygens and consequently an increase in the dielectric permittivity [7] [18] [20] [21].

\section{Experimental Procedures}

A glass of composition $\mathrm{xLi}_{2} \mathrm{O}-\mathrm{yCr} \mathrm{O}_{2} \mathrm{O}_{3}-\left(100-(\mathrm{x}+\mathrm{y}) \mathrm{P}_{2} \mathrm{O}_{5}\right.$ (mol \%) was obtained by the melting quench method at $1000^{\circ} \mathrm{C}$. Appropriate mixtures of the compounds $\mathrm{Li}_{2} \mathrm{CO}_{3}, \mathrm{Cr}_{2} \mathrm{O}_{3}$ and $\left(\mathrm{NH}_{4}\right)_{2} \mathrm{HPO}_{4}$ were initially prepared at various temperatures between $300^{\circ} \mathrm{C}-500^{\circ} \mathrm{C}$ in order to achieve a preliminary preparation before the final glass preparation. The melts were performed in alumina crucibles for about $20 \mathrm{~min}$ at $1000^{\circ} \mathrm{C} \pm 10^{\circ} \mathrm{C}$. The isolated glass samples were approximately $10 \mathrm{~mm}$ diameter and 1 to $3 \mathrm{~mm}$ in thickness. Their vitreous state was first evidenced by their shiny aspect and confirmed by XRD. Annealing of these glasses was realised at increasing temperatures in intervals of $100^{\circ} \mathrm{C}$. The first structural approach was X-ray diffraction, which allowed the crystallisation of the vitreous domain $\mathrm{Li}_{2} \mathrm{O}-\mathrm{P}_{2} \mathrm{O}_{5}-\mathrm{Cr}_{2} \mathrm{O}_{3}$ to be followed. The dielectric permittivity $\left(\varepsilon_{r}^{\prime}\right)$ and di- 
electric loss $(\operatorname{tn} \delta)$ measurements were determined from capacity measurements realised on samples in the form of small cylinders carved with abrasive papers. While depositing a layer of silver lacque on the parallel faces of the samples, we form a condenser plan of which the capacity is measured using a Hewlett Packard 4262 A LCR Meter. The measures of conductivity were determined from resistivity measurements realised on samples. The samples were polished in the form of small cylinders using abrasive papers. Pastilles so obtained have diameters of around $10 \mathrm{~mm}$ and thicknesses varying between 1 and $3 \mathrm{~mm}$.

\section{Results}

In the $\mathrm{Li}_{2} \mathrm{O}-\mathrm{P}_{2} \mathrm{O}_{5}$ system, transparent and colourless glasses could be prepared with molar fractions of $\mathrm{Li}_{2} \mathrm{O}$ between 0 and 0.62 . These values are in good agreement with previously published results [18] but are rather superior to those given by the other authors [20] [22]. This is probably caused by different experimental conditions (temperature of melting; speed of tempering, etc.) [23]. In the binary system $\mathrm{Cr}_{2} \mathrm{O}_{3}-\mathrm{P}_{2} \mathrm{O}_{5}$, the substitution of $\mathrm{P}_{2} \mathrm{O}_{5}$ by $\mathrm{Cr}_{2} \mathrm{O}_{3}$ led to very hygroscopic green glasses with a chromium oxide content between 0 and $7 \mathrm{~mol} \%$, see Figure 1. Ternary glasses have also a green colour which becomes more clear and green as the lithium oxide content increases and as the $\mathrm{Cr}_{2} \mathrm{O}_{3}$ content increases between $0 \leq \mathrm{y}<5$; ( $\mathrm{mol} \%)$. The demarcation of the glassy zone within the ternary diagramLi ${ }_{2} \mathrm{O}-\mathrm{P}_{2} \mathrm{O}_{5}-\mathrm{Cr}_{2} \mathrm{O}_{3}$ is given by the following limits: $0 \leq \mathrm{x} \leq 62$; $0 \leq \mathrm{y}<7 ; 36 \leq \chi \leq 100$ (mol\%) (Figure 1). The localization of analysed compounds is presented inside the ternary diagram given in Figure 2 .

\subsection{Annealing Temperature}

The annealing temperatures of the binary $\mathrm{Li}_{2} \mathrm{O}-\mathrm{P}_{2} \mathrm{O}_{5}$, ternaries glasses and ceramic glasses were tested at increasing temperatures in intervals of $100^{\circ} \mathrm{C}$. Increasing amounts of the lithium oxide modifier lead to an increase of the values for the crystallisation temperature. For the glasses and ceramic glasses of composition $\mathrm{xLi}_{2} \mathrm{O}-2 \mathrm{Cr}_{2} \mathrm{O}_{3}-(98-\chi) \mathrm{P}_{2} \mathrm{O}_{5}$ and $\mathrm{xLi}_{2} \mathrm{O}-5 \mathrm{Cr}_{2} \mathrm{O}_{3}-(98-\chi) \mathrm{P}_{2} \mathrm{O}_{5}$, Figure 3 shows that the crystallisation temperature increases from $(250 \pm 10)^{\circ} \mathrm{C}$ to $(540 \pm$

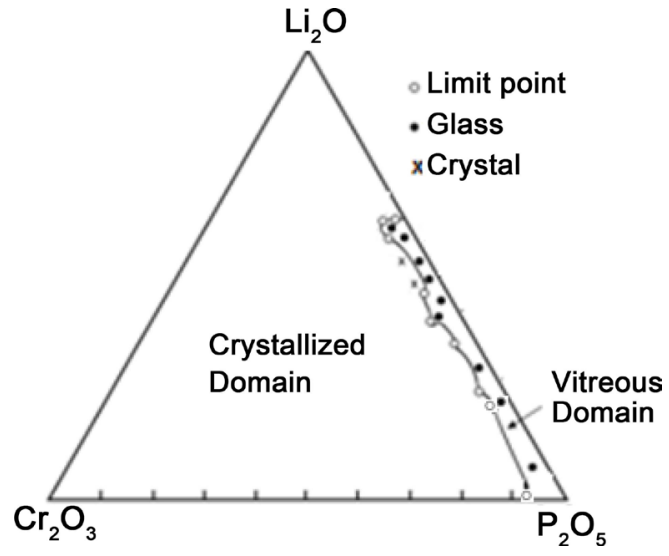

Figure 1. Extended from the vitreous field within the ternary diagram $\mathrm{Li}_{2} \mathrm{O}-\mathrm{P}_{2} \mathrm{O}_{5}-\mathrm{Cr}_{2} \mathrm{O}_{3}$ to $1000^{\circ} \mathrm{C}$. 


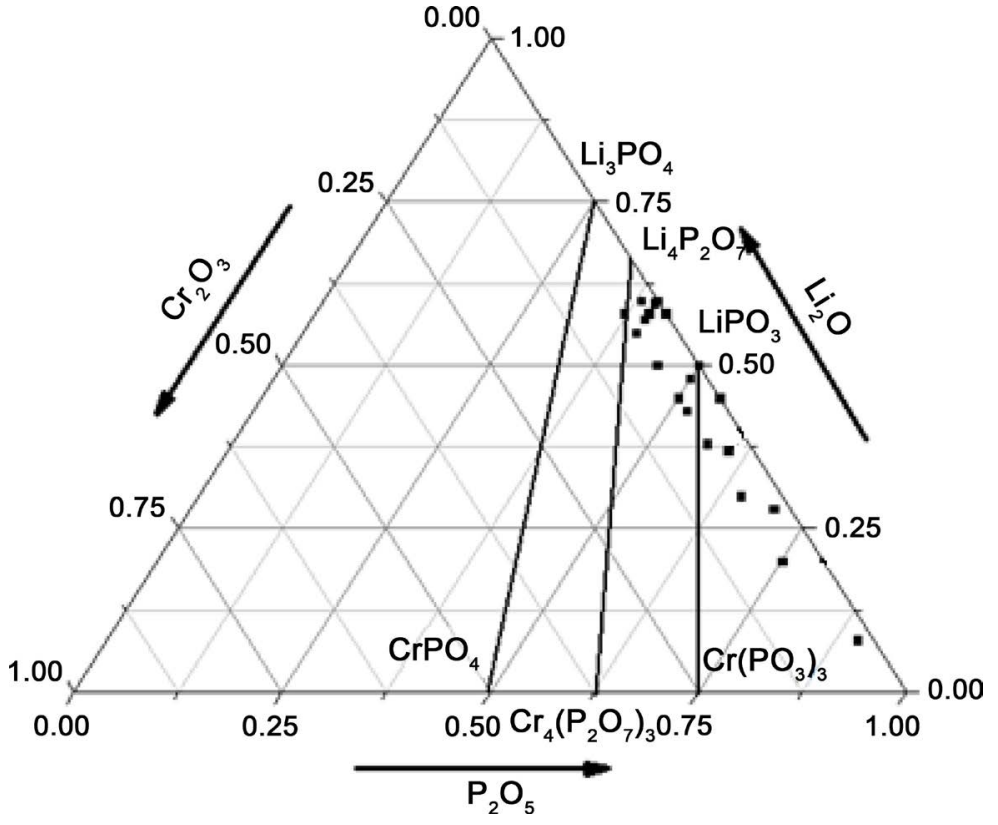

Figure 2. Localization of the investigatedglass and ceramic glass compositionsin the ternary diagram $\mathrm{Li}_{2} \mathrm{O}-\mathrm{Cr}_{2} \mathrm{O}_{3}-\mathrm{P}_{2} \mathrm{O}_{5}$.

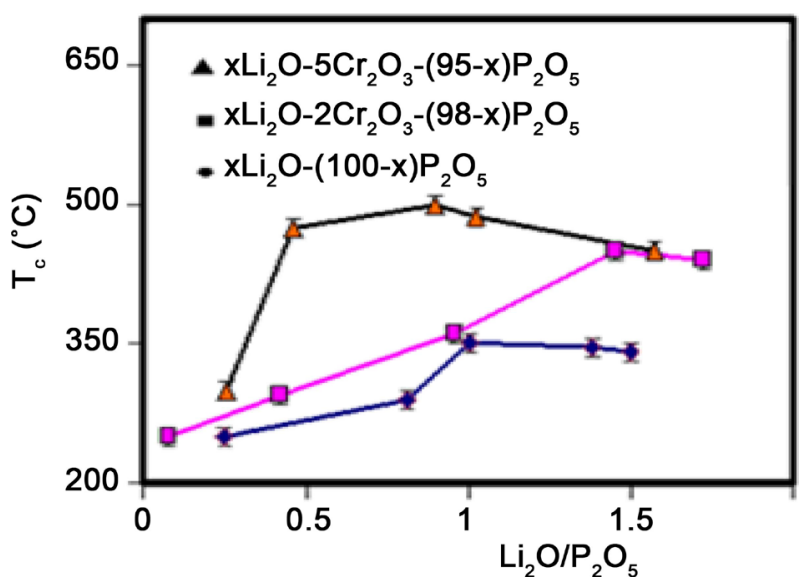

Figure 3. Variation of crystallization temperature as a function of the $\mathrm{Li}_{2} \mathrm{O} / \mathrm{P}_{2} \mathrm{O}_{5}$ ratio for glasses and ceramic glasses with the composition $\mathrm{Li}_{2} \mathrm{O}-\mathrm{Cr}_{2} \mathrm{O}_{3}-\mathrm{P}_{2} \mathrm{O}_{5}$.

10) ${ }^{\circ} \mathrm{C}$ as the $\mathrm{Li}_{2} \mathrm{O} / \mathrm{P}_{2} \mathrm{O}_{5}$ ratio increases from 0 to 2 . However, the annealing temperature (Tc) variations for the ceramic glasses are greater than those observed in the glasses when the $\mathrm{Li}_{2} \mathrm{O}$ content increases.

\subsection{Electrical Conductivity}

The electrical conductivities were measured at various temperatures between $25^{\circ} \mathrm{C}$ and $300^{\circ} \mathrm{C}$. Figure 4 shows the variation of the logarithm of the conductivity as a function of the inverse of the absolute temperature for some compositions. In a large part of the envisaged domain of temperature, the conductivity $\sigma$ varies according to Arrhenius's law $\sigma_{0} \operatorname{Exp} \mathrm{Ea} / \mathrm{kT}$ where $\sigma_{0}$ is the pre-exponential term, Ea is the activation energy of conduction, and $\mathrm{k}$ is the Boltzmann constant, $1.38 \times 10^{-23} \mathrm{~J} / \mathrm{K}$. The activation energies, Ea, calculated from this relationship are 
shown in Table 1 as are the conductivities at $300^{\circ} \mathrm{C}$. Examination of this table shows that the activation energy is a decreasing function of the $\mathrm{Li}_{2} \mathrm{O}$ content. Figure 5 clearly indicates the variations of the conductivity at $300^{\circ} \mathrm{C}$ according to the $\mathrm{Li}_{2} \mathrm{O}$ content for the glasses and glass ceramics with different $\mathrm{Cr}_{2} \mathrm{O}_{3}$ contents. We can conclude that the introduction of chromium oxide into the phosphate network seems to change the behaviour from that of a glass to that of a ceramic glass. We note a decrease of $\sigma$ for glasses, whereas we observe an increase of $\sigma$ for ceramic glasses. On the other hand Figure 6 indicates that the

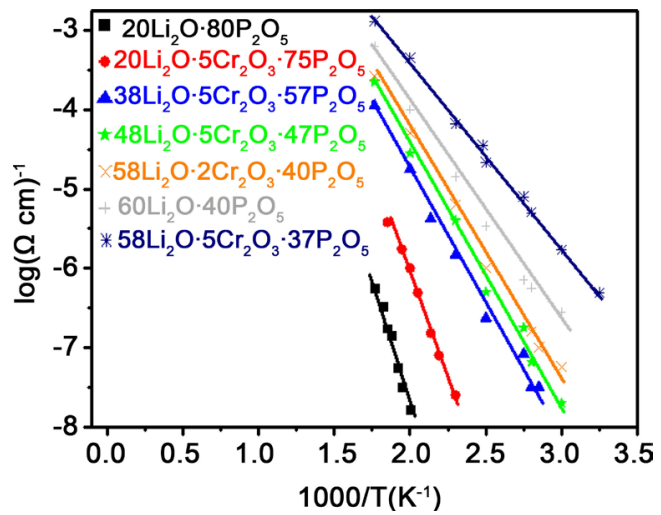

Figure 4. The Arrhenius plot for some glasses and glass-ceramics, (mol\%) in the ternary diagram $\mathrm{Li}_{2} \mathrm{O}-\mathrm{Cr}_{2} \mathrm{O}_{3}-\mathrm{P}_{2} \mathrm{O}_{5}$.

Table 1. Glasses and ceramic glasses composition in mol\% and selected properties as electrical conductivity and activation energies.

\begin{tabular}{ccc}
\hline Batch Composition (mol\%) & $\sigma(\Omega \mathrm{cm})^{-1}$ at $300^{\circ} \mathrm{C}$ & Activation energy Ea (e.v) \\
\hline $60 \mathrm{Li}_{2} \mathrm{O} \cdot 40 \mathrm{P}_{2} \mathrm{O}_{5}$ & $5.7 \times 10^{-4}$ & 0.53 \\
$20 \mathrm{Li}_{2} \mathrm{O} \cdot 80 \mathrm{P}_{2} \mathrm{O}_{5}$ & $1.1 \times 10^{-6}$ & 1.07 \\
$58 \mathrm{Li}_{2} \mathrm{O} \cdot 2 \mathrm{Cr}_{2} \mathrm{O}_{3} \cdot 40 \mathrm{P}_{2} \mathrm{O}_{5}$ & $2.5 \times 10^{-5}$ & 0.59 \\
$58 \mathrm{Li}_{2} \mathrm{O} \cdot 5 \mathrm{Cr}_{2} \mathrm{O}_{3} \cdot 37 \mathrm{P}_{2} \mathrm{O}_{5}$ & $2.0 \times 10^{-3}$ & 0.45 \\
$48 \mathrm{Li}_{2} \mathrm{O} \cdot 5 \mathrm{Cr}_{2} \mathrm{O}_{3} \cdot 47 \mathrm{P}_{2} \mathrm{O}_{5}$ & $4.7 \times 10^{-5}$ & 0.69 \\
$38 \mathrm{Li}_{2} \mathrm{O} \cdot 5 \mathrm{Cr}_{2} \mathrm{O}_{3} \cdot 57 \mathrm{P}_{2} \mathrm{O}_{5}$ & $1.4 \times 10^{-4}$ & 0.70 \\
$20 \mathrm{Li}_{2} \mathrm{O} \cdot 5 \mathrm{Cr}_{2} \mathrm{O}_{3} \cdot 75 \mathrm{P}_{2} \mathrm{O}_{5}$ & $2.2 \times 10^{-5}$ & 0.93 \\
\hline
\end{tabular}

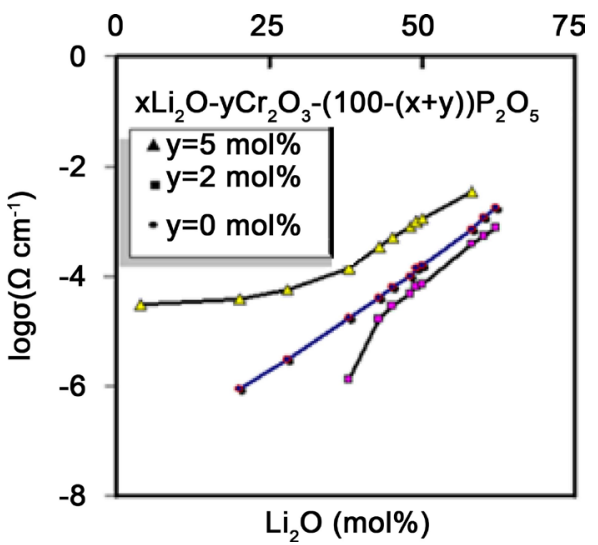

Figure 5. Variation of the conductivity logarithm at $300^{\circ} \mathrm{C}$ as a function of $\mathrm{Li}_{2} \mathrm{O}$ content for some glasses and ceramic glasses in the ternary diagram $\mathrm{Li}_{2} \mathrm{O}-\mathrm{Cr}_{2} \mathrm{O}_{3}-\mathrm{P}_{2} \mathrm{O}_{5}$. 


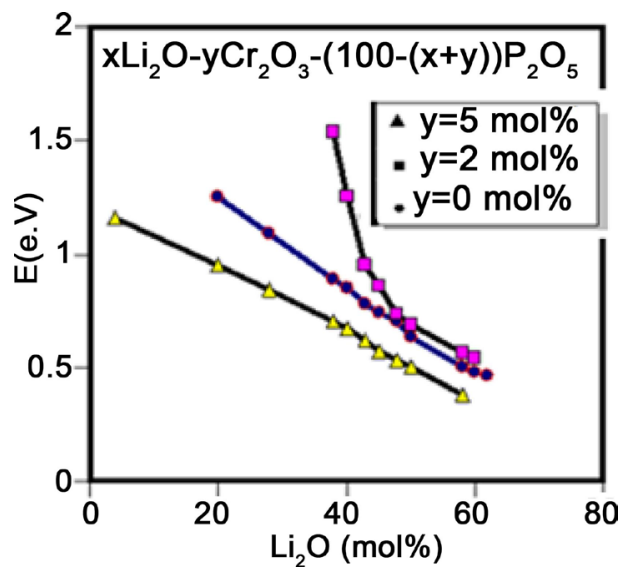

Figure 6. Variation of the activation energy at $300^{\circ} \mathrm{C}$ as a function of $\mathrm{Li}_{2} \mathrm{O}$ content for some glasses and ceramic glasses in the ternary diagram $\mathrm{Li}_{2} \mathrm{O}-\mathrm{Cr}_{2} \mathrm{O}_{3}-\mathrm{P}_{2} \mathrm{O}_{5}$.

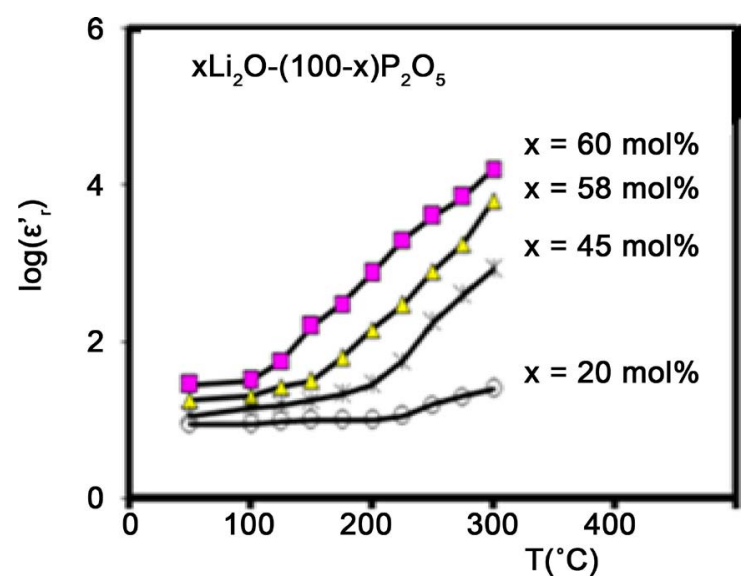

Figure 7. Variation of dielectric permittivity with temperature at $10 \mathrm{KHz}$ of binary glasses with the composition $\mathrm{x} \mathrm{Li}{ }_{2} \mathrm{O}-(100-\mathrm{x}) \mathrm{P}_{2} \mathrm{O}_{5}$.

activation energies, for different lines, varies inversely proportionnel with the increase of the $\mathrm{Li}_{2} \mathrm{O}$ content [7] [18] [20] [24].

\subsection{Dielectric Permittivity}

Figures 7-9 show the thermal variations of $\log \varepsilon_{r}^{\prime}$ for three families of composition: $\mathrm{xLi}_{2} \mathrm{O}-(100-\mathrm{x}) \mathrm{P}_{2} \mathrm{O}_{5} ; \mathrm{xLi}_{2} \mathrm{O}-2 \mathrm{Cr}_{2} \mathrm{O}_{3}-(98-\mathrm{x}) \mathrm{P}_{2} \mathrm{O}_{5}$; and $\mathrm{xLi}_{2} \mathrm{O}-5 \mathrm{Cr}_{2} \mathrm{O}_{3}-(95-\mathrm{x})$ $\mathrm{P}_{2} \mathrm{O}_{5}$. Examination of these figures shows that when the temperature and the composition are modified, the variation in the dielectric values is proportionally greater than those of silicate glasses [1] [2] [3]. However the values of $\varepsilon_{r}^{\prime}$ remain very modest below a certain temperature $\left(\mathrm{T}_{\mathrm{t}}\right)$ after which the $\log \varepsilon_{r}^{\prime}$ slope increases more and more quickly with increased $\mathrm{Li}_{2} \mathrm{O}$ content. Figure 10 shows that the curve $\left(T_{t}\right)$ changes according to the $\mathrm{Li}_{2} \mathrm{O}$ content $\left(\log \varepsilon_{r}^{\prime}=f\left(T_{t}\right)\right)$ for all different lines studied, manifested as an increase in $\log \varepsilon_{r}^{\prime}$, and a negative slope. The results are regrouped in Table 2. The study of the $T_{t}$ in relation to the $\mathrm{Li}_{2} \mathrm{O}$ content shows that when the $\mathrm{Li}_{2} \mathrm{O}$ content increases for various compositions, the temperature decreases. Similar results have been shown in previous studies [18] [20]. 


\subsection{Dielectric Loss}

Figures 11-13 show the curves representing thermal variations of the dielectric

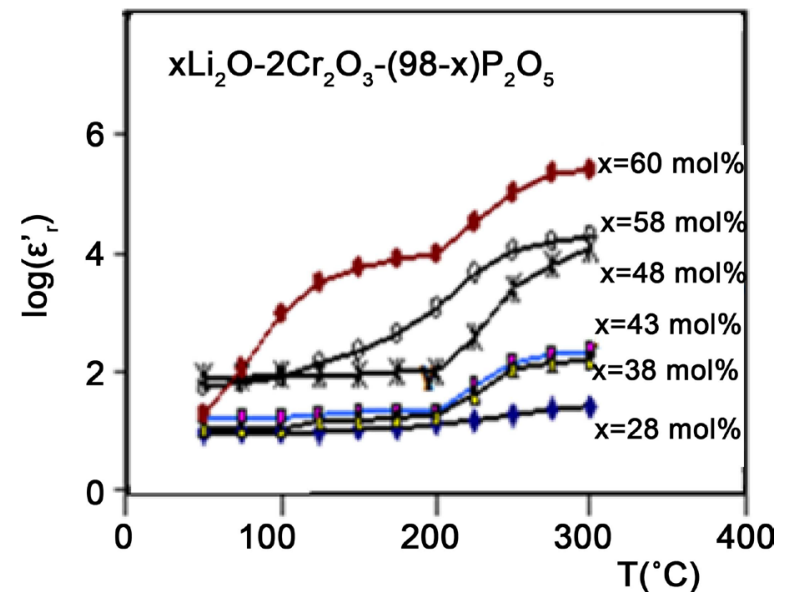

Figure 8. Variation of dielectric permittivity with temperature at $10 \mathrm{KHz}$ for glasses with the composition $-\mathrm{xLi}_{2} \mathrm{O}-2 \mathrm{Cr}_{2} \mathrm{O}_{3}(98-\mathrm{x}) \mathrm{P}_{2} \mathrm{O}_{5}$.

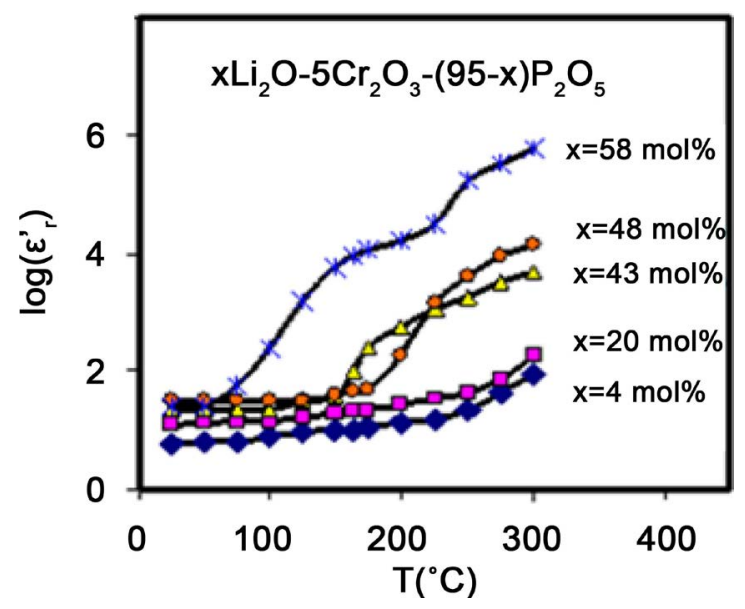

Figure 9. Variation of dielectric permittivity with temperature at $10 \mathrm{KHz}$ for ceramic glasses with the composition $\mathrm{xLi}_{2} \mathrm{O}-5 \mathrm{Cr}_{2} \mathrm{O}_{3}-(95-\mathrm{x}) \mathrm{P}_{2} \mathrm{O}_{5}$.

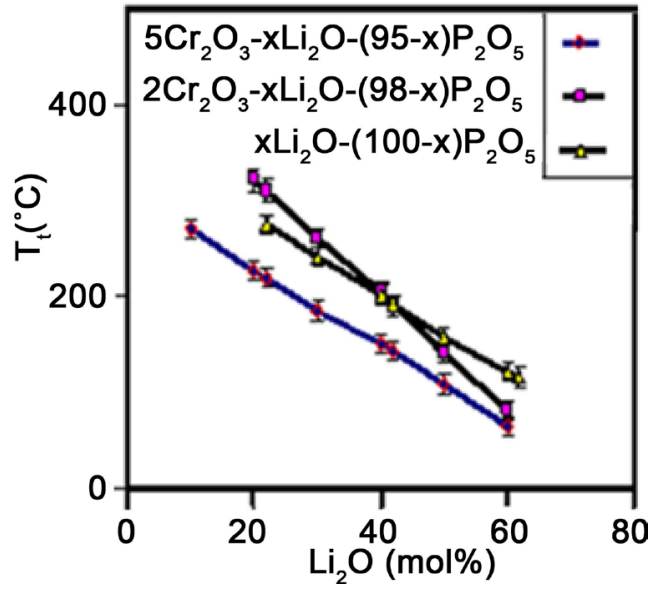

Figure 10. Variation of $\mathrm{T}_{\mathrm{t}}$ as a function of the $\mathrm{Li}_{2} \mathrm{O}$ content for glasses and ceramic glasses with the composition $\mathrm{x} \mathrm{Li}_{2} \mathrm{O}-\mathrm{yCr} \mathrm{O}_{2} \mathrm{O}_{3}-(100-(\mathrm{x}+\mathrm{y})) \mathrm{P}_{2} \mathrm{O}_{5}$. 
Table 2. Glasses and ceramic glasses composition in mol\% and selected properties as Permittivity and $\mathrm{T}_{\mathrm{t}}$.

\begin{tabular}{ccc}
\hline Batch Composition $(m o l \%)$ & Permittivity $\varepsilon_{r}^{\prime}$ at $300^{\circ} \mathrm{C}$ & $\mathrm{T}_{\mathrm{t}}\left({ }^{\circ} \mathrm{C}\right)$ \\
\hline $62 \mathrm{Li}_{2} \mathrm{O} \cdot 38 \mathrm{P}_{2} \mathrm{O}_{5}$ & 56,234 & 76 \\
$60 \mathrm{Li}_{2} \mathrm{O} \cdot 40 \mathrm{P}_{2} \mathrm{O}_{5}$ & $43,651.6$ & 110 \\
$59,5 \mathrm{Li}_{2} \mathrm{O} \cdot 0,5 \mathrm{Cr}_{2} \mathrm{O}_{3} \cdot 40 \mathrm{P}_{2} \mathrm{O}_{5}$ & - & - \\
$58 \mathrm{Li}_{2} \mathrm{O} \cdot 42 \mathrm{P}_{2} \mathrm{O}_{5}$ & 6309.6 & 115 \\
$45 \mathrm{Li}_{2} \mathrm{O} \cdot 50 \mathrm{P}_{2} \mathrm{O}_{5}$ & 537 & 210 \\
$60 \mathrm{Li}_{2} \mathrm{O} \cdot 2 \mathrm{Cr}_{2} \mathrm{O}_{3} \cdot 48 \mathrm{P}_{2} \mathrm{O}_{5}$ & $5 \times 10^{5}$ & 50 \\
$58 \mathrm{Li}_{2} \mathrm{O} \cdot 2 \mathrm{Cr}_{2} \mathrm{O}_{3} \cdot 40 \mathrm{P}_{2} \mathrm{O}_{5}$ & $17,782.8$ & 96 \\
$57 \mathrm{Li}_{2} \mathrm{O} \cdot 3 \mathrm{Cr}_{2} \mathrm{O}_{3} \cdot 40 \mathrm{P}_{2} \mathrm{O}_{5}$ & - & - \\
$55 \mathrm{Li}_{2} \mathrm{O} \cdot 5 \mathrm{Cr}_{2} \mathrm{O}_{3} \cdot 40 \mathrm{P}_{2} \mathrm{O}_{5}$ & - & - \\
$48 \mathrm{Li}_{2} \mathrm{O} \cdot 2 \mathrm{Cr}_{2} \mathrm{O}_{3} \cdot 50 \mathrm{P}_{2} \mathrm{O}_{5}$ & 7585.8 & 181 \\
$43 \mathrm{Li}_{2} \mathrm{O} \cdot 2 \mathrm{Cr}_{2} \mathrm{O}_{3} \cdot 55 \mathrm{P}_{2} \mathrm{O}_{5}$ & 234.4 & 200 \\
$38 \mathrm{Li}_{2} \mathrm{O} \cdot 2 \mathrm{Cr}_{2} \mathrm{O}_{3} \cdot 60 \mathrm{P}_{2} \mathrm{O}_{5}$ & 199.5 & 228 \\
$28 \mathrm{Li}_{2} \mathrm{O} \cdot 2 \mathrm{Cr}_{2} \mathrm{O}_{3} \cdot 70 \mathrm{P}_{2} \mathrm{O}_{5}$ & 23.71 & 190 \\
$58 \mathrm{Li}_{2} \mathrm{O} 5 \cdot \mathrm{Cr}_{2} \mathrm{O}_{3} \cdot 37 \mathrm{P}_{2} \mathrm{O}_{5}$ & $7.94 \times 10^{5}$ & 63 \\
$48 \mathrm{Li}_{2} \mathrm{O} \cdot 5 \mathrm{Cr}_{2} \mathrm{O}_{3} \cdot 47 \mathrm{P}_{2} \mathrm{O}_{5}$ & 10,000 & 170 \\
$43 \mathrm{Li}_{2} \mathrm{O} \cdot 5 \mathrm{Cr}_{2} \mathrm{O}_{3} \cdot 52 \mathrm{P}_{2} \mathrm{O}_{5}$ & 2238.7 & 149 \\
$20 \mathrm{Li}_{2} \mathrm{O} \cdot 5 \mathrm{Cr}_{2} \mathrm{O}_{3} \cdot 75 \mathrm{P}_{2} \mathrm{O}_{5}$ & 63.1 & 190 \\
$4 \mathrm{Li}_{2} \mathrm{O} \cdot 5 \mathrm{Cr}_{2} \mathrm{O}_{3} \cdot 91 \mathrm{P}_{2} \mathrm{O}_{5}$ & & 2 \\
\hline
\end{tabular}

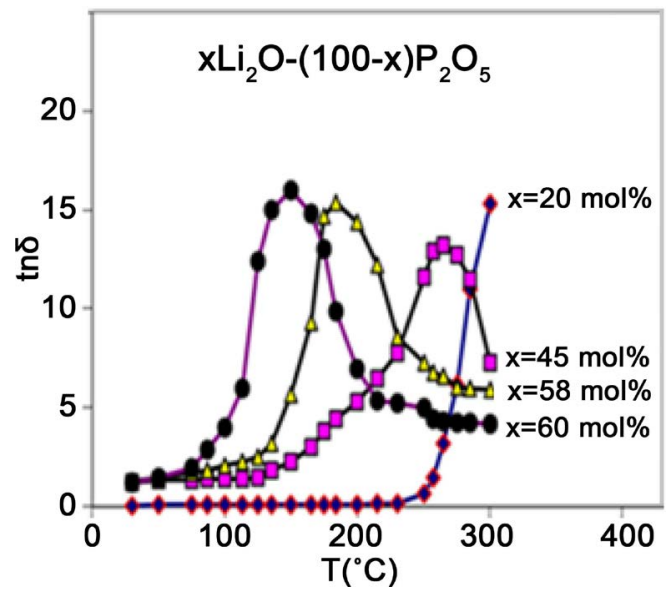

Figure 11. Thermal variation of dielectric losses at $10 \mathrm{Khz}$ of glasses with the composition $\mathrm{xLi}_{2} \mathrm{O}-(100-\mathrm{x}) \mathrm{P}_{2} \mathrm{O}_{5}$.

losses of glasses and vitreous ceramics of the ternary system $\mathrm{Li}_{2} \mathrm{O}-\mathrm{P}_{2} \mathrm{O}_{5}-\mathrm{Cr}_{2} \mathrm{O}_{3}$. These curves show a more or less Gaussian behaviour with maxima of $\operatorname{tn} \delta$, which appear at decreasing temperatures as the $\mathrm{Li}_{2} \mathrm{O}$ content increases. The temperatures of these maxima seem to coincide with the $\mathrm{Tt}$ observed on the log $\varepsilon_{r}^{\prime} \quad\left(T_{t}\right)$ curves. Moreover, Figure 14 shows that the increase in $\mathrm{Cr}_{2} \mathrm{O}_{3}$ content in the ulraphosphate units $(50 \leq \chi \leq 100$; mol\%) does not seem to have a notable 


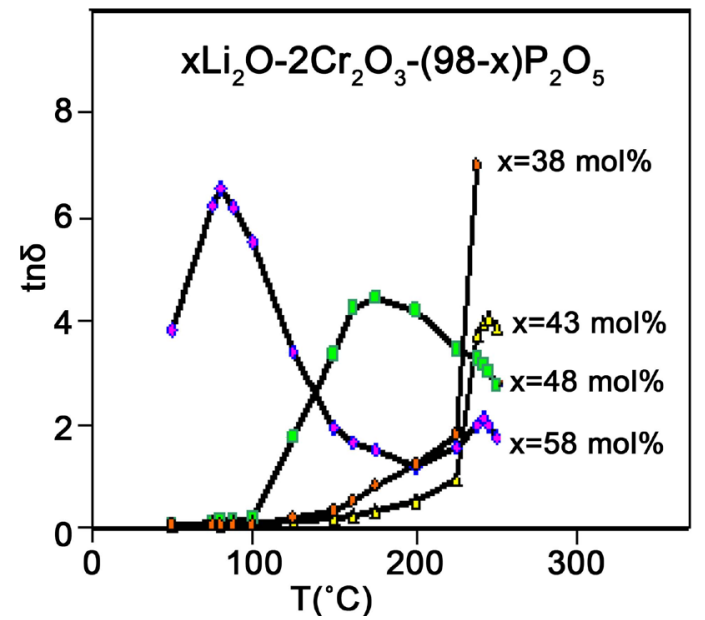

Figure 12. Thermal variation of dielectric losses at $10 \mathrm{Khz}$ of ceramic glasses with the composition $\mathrm{xLi}_{2} \mathrm{O}-2 \mathrm{Cr}_{2} \mathrm{O}_{3}-(98-\mathrm{x}) \mathrm{P}_{2} \mathrm{O}_{5}$.

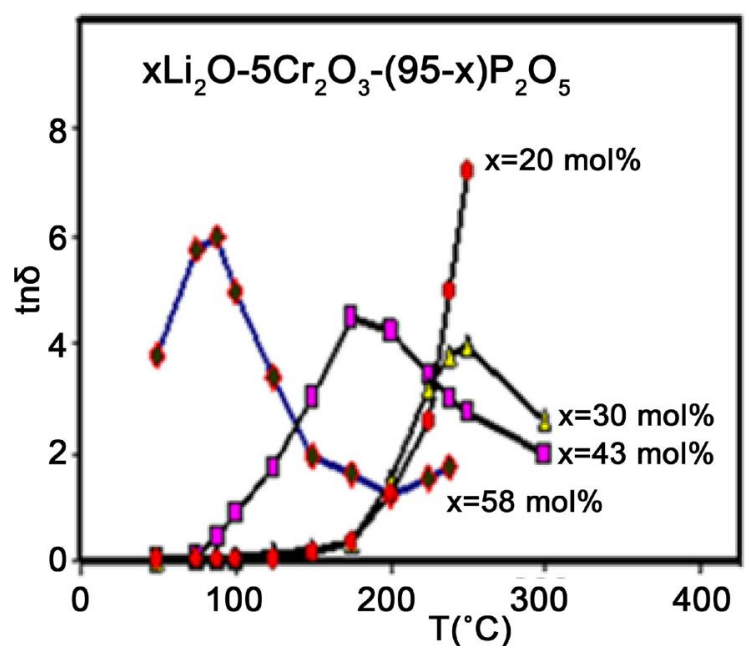

Figure 13. Thermal variation of dielectric losses at $10 \mathrm{Khz}$ of ceramic glasses with the composition $\mathrm{Li}_{2} \mathrm{O}-5 \mathrm{Cr}_{2} \mathrm{O}_{3}-(95-\mathrm{x}) \mathrm{P}_{2} \mathrm{O}_{5}$.

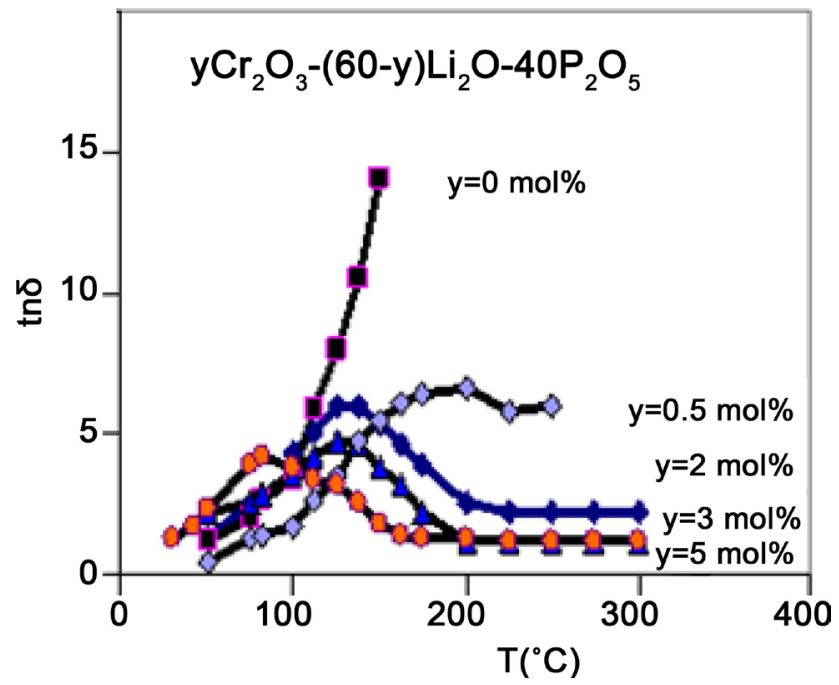

Figure 14. Thermal variation of dielectric losses at $10 \mathrm{Khz}$ of glasses and ceramic glasses with the composition $(60-\mathrm{y}) \mathrm{Li}_{2} \mathrm{O}-\mathrm{yCr}_{2} \mathrm{O}_{3}-40 \mathrm{P}_{2} \mathrm{O}_{5}$. 
influence on the position of the maxima of $\operatorname{tn} \delta(\mathrm{T})$ for the glasses and the vitreous ceramics, but specially induces the decrease of the amplitude of the dielectric losses.

\subsection{Infrared Spectroscopy}

The infrared spectra of the glasses of the binary system $\mathrm{Li}_{2} \mathrm{O}-\mathrm{P}_{2} \mathrm{O}_{5}$ are shown in Figure 15. Increase of the lithium oxide content in the phosphate glasses causes an important depolymerisation in the vitreous network, and induces the formation of small units in accordance with the results of M. Ouchetto et al. [18] [19] [25]. The analysis of infra-red spectra shows that the band at $455-500 \mathrm{~cm}^{-1}$ is assigned to the deformation of the skeleton $\delta$ ske (P-O-P while the band at 735 $775 \mathrm{~cm}^{-1}$ and the bands at $900-910 \mathrm{~cm}^{-1}$ are assigned respectively to the vibration of symmetric stretching $v s_{y m}\left(\mathrm{P}-\mathrm{O}-\mathrm{P}\right.$ and to the asymmetric stretching $v_{a s y m}$ (P-O-P) [9] [11]. The band $v_{\mathrm{as}} \mathrm{PO}_{2}$ that appears about $1250-1275 \mathrm{~cm}^{-1}$, attributed to $\mathrm{Q}^{2}$ phosphate tetrahedron, decreases while we move away from point $\mathrm{P}_{2} \mathrm{O}_{5}$. Whereas the band $v s \mathrm{PO}_{2}$ that appears about $1090-1100 \mathrm{~cm}^{-1}$ attributed to $\mathrm{Q}^{1}$ phosphate tetrahedron, increases with the increasing of $\mathrm{Li}_{2} \mathrm{O}$ content and inducts a break links P-O-P and an increase of the number of non bridge-oxygen. In the other hand, the IR spectra with the compositions $\mathrm{xLi}_{2} \mathrm{O}-2 \mathrm{Cr}_{2} \mathrm{O}_{3}-(98-\mathrm{x}) \mathrm{P}_{2} \mathrm{O}_{5}$ and $\mathrm{xLi}_{2} \mathrm{O}-5 \mathrm{Cr}_{2} \mathrm{O}_{3}-(95-\mathrm{x}) \mathrm{P}_{2} \mathrm{O}_{5}$, observed in the Figure 16 and Figure 17 respectively, have similar behaviours to the spectra of the binary system $\mathrm{xLi}_{2} \mathrm{O}-(100-\mathrm{x}) \mathrm{P}_{2} \mathrm{O}_{5}$ family, which can be explained by a similar structural evolution [7]. We note the presence of a small band vas P-O-P at $995-998 \mathrm{~cm}^{-1}$, attributed to isolated orthophosphate units, when the $\mathrm{Li}_{2} \mathrm{O}$ content exceeds $55 \mathrm{~mol} \%$. This last one can be attributed to the $\mathrm{Cr}-\mathrm{O}-\mathrm{P}$ bond in $\mathrm{CrPO}_{4}$ units [26]. Also, the band vsP $=0$ that appears about $1360 \mathrm{~cm}^{-1}$ diminishes while on moves away from point $\mathrm{P}_{2} \mathrm{O}_{5}$, that seems to be attributed to the basic glass matrix $\mathrm{P}_{2} \mathrm{O}_{5}[18]$.

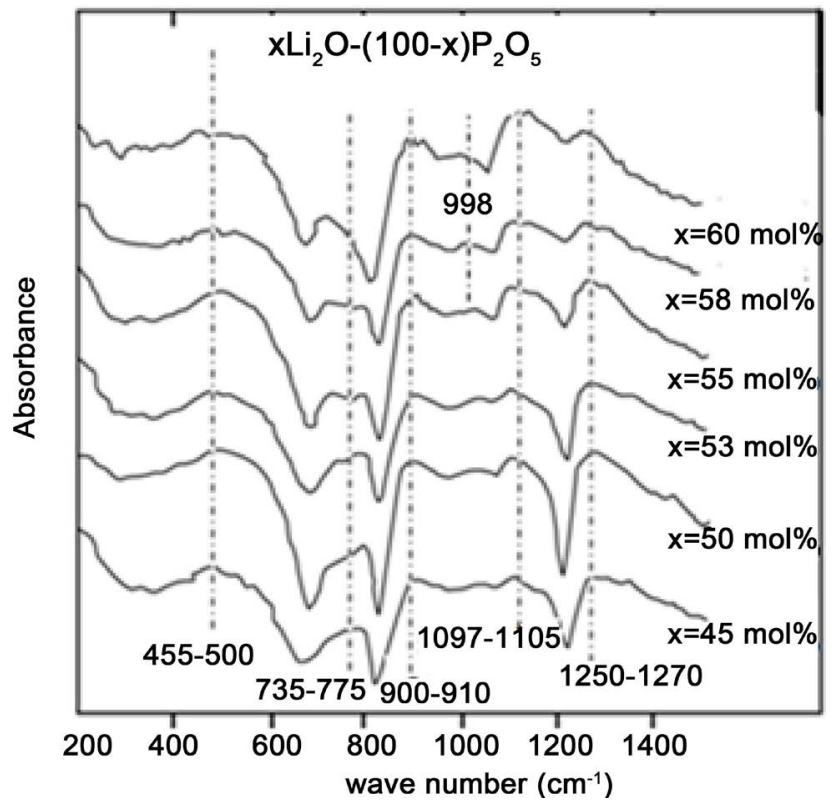

Figure 15. I.R spectra of phosphate glasses with the composition $x \mathrm{Li}_{2} \mathrm{O}-(100-\mathrm{x}) \mathrm{P}_{2} \mathrm{O}_{5}$. 


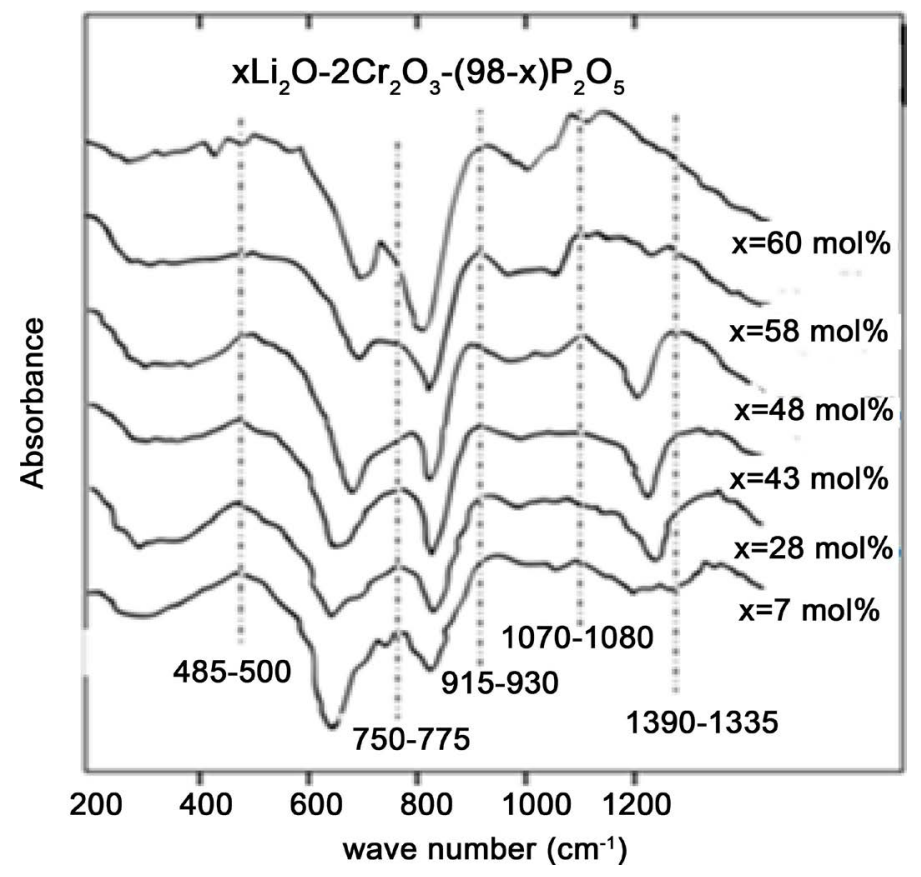

Figure 16. I.R spectra of chromium phosphate glasses with the composition $\mathrm{xLi}_{2} \mathrm{O}$ $2 \mathrm{Cr}_{2} \mathrm{O}_{3}-(98-\mathrm{x}) \mathrm{P}_{2} \mathrm{O}_{5}$.

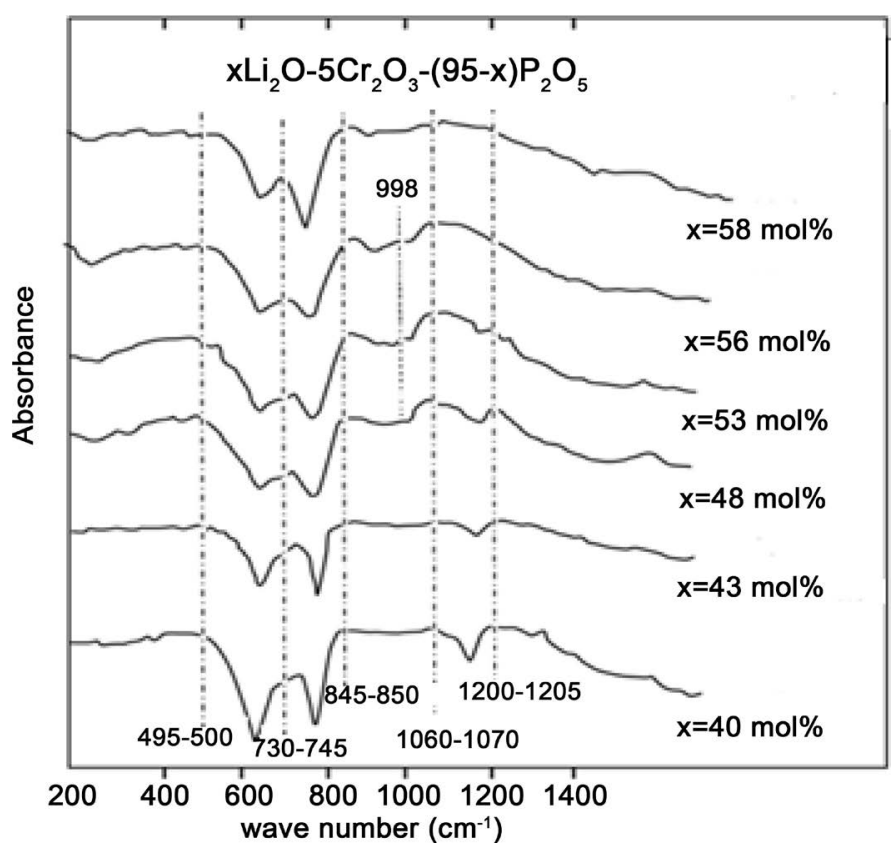

Figure 17. I.R spectra of chromium phosphate ceramic glasses with the composition $\mathrm{xLi}_{2} \mathrm{O}-5 \mathrm{Cr}_{2} \mathrm{O}_{3}-(95-\mathrm{x}) \mathrm{P}_{2} \mathrm{O}_{5}$.

\section{Discussion}

The regular melting-quench method allowed the isolation of a small vitreous domain within the ternary system $\mathrm{Li}_{2} \mathrm{O}-\mathrm{P}_{2} \mathrm{O}_{5}-\mathrm{Cr}_{2} \mathrm{O}_{3}$ at $1000^{\circ} \mathrm{C}$. Conductivity measurements were performed on glasses and vitreous ceramics isolated within the ternary systemLi $\mathrm{O}_{2} \mathrm{O}-\mathrm{P}_{2} \mathrm{O}_{5}-\mathrm{Cr}_{2} \mathrm{O}_{3}$. Dielectric permittivity and dielectric loss were measured at a frequency of $10 \mathrm{kHz}$ and in the temperature range of 298 to 
$573 \mathrm{~K}$. An increase in the $\mathrm{Li}_{2} \mathrm{O}$ content in the glass network results at the same time in an increase in $\varepsilon_{r}^{\prime}(\mathrm{T})$ and an increase in $\operatorname{tg} \delta$. These phenomena result from a increasing depolymerisation of the glass network due to increased numbers of non-bridge oxygens because of the progressive breaking of phosphorus network links as the modifier $\mathrm{Li}_{2} \mathrm{O}$ content increases [7] [18] [21]. Indeed, the oxide modifier $\mathrm{Li}_{2} \mathrm{O}$ has much lower link energies than those of the formative oxides [24]. As a consequence the mobile lithium ion is weakly connected to the network and will be thermally activated to cross the barriers of potential presented by the network, involving the formation of non-bridge oxygens by the breaking of P-O-P links. This leads to the formation of the - P - O- entities, which are easily polarised, hence the increase in $\varepsilon_{r}^{\prime}$. On the other hand, more the concentration of the modifier oxide increases, the greater the number of lithium-oxygen-phosphorus bonds in the vitreous network more the calorific energy needed to break the potential barriers presented by the network is low, hence, temperature $\left(T_{t}\right)$ decreases. However, an increase in chromium oxide content, even at very low concentration, induces a decrease of the dielectric losses and an increase of the $T_{t}$ temperature. Hence we can say that an increase in $\mathrm{Cr}_{2} \mathrm{O}_{3}$ content induces an increase of the rigidity of the glass network. However, this behaviour changes when the system changes from a glass to a ceramic glass. The study of the conductivity as a function of the temperature for various samples shows that $\sigma$ varies according to Arrhenius's law. Increase in temperature and $\mathrm{Li}_{2} \mathrm{O}$ content both induce an important increase in the conductivity. The mobile lithium ion $\left(\mathrm{Li}^{+}\right)$is weakly connected to the network and will be thermally activated to cross the potential barriers presented by the network. This leads to the initiation of greater ionic conduction as the number of free $\mathrm{Li}^{+}$ions increases. The effects of $\mathrm{Cr}_{2} \mathrm{O}_{3}$ on the conductivity and the activation energy in glasses and ceramic glasses are different. We note that the conductivity decreases in the glasses followed by an increase of the activation energy, while the conductivity increases in vitreous ceramics followed by a decrease of the activation energy. However the decrease of $\sigma$ in the chromium glasses can be explained by the replacement of Li-O-P or P-O-P hydrated bonds by $\mathrm{Cr}-\mathrm{O}-\mathrm{P}$ covalent bonds. $\mathrm{Cr}^{3+}$ ions would be trapped in sites of low coordination $(\leq 6)$ and so would be a part of the formative network [27]. The glassy domain bounded in our experimental conditions $\left(\mathrm{T}_{\mathrm{f}}=1000^{\circ} \mathrm{C}\right)$ is relatively small and the vitreous ceramics studied have a composition rather close to the border area separating glassy and crystallised domains inside the ternary structure $\mathrm{Li}_{2} \mathrm{O}-\mathrm{P}_{2} \mathrm{O}_{5}-\mathrm{Cr}_{2} \mathrm{O}_{3}$. Thus, the network defects are probably more numerous there and in a favourable position with regard to the mobile species. We can conclude that the conductivity seems to improve when we pass from the glassy domain to the vitreous ceramic domain [28]. At the same time, the increased $\mathrm{Li}_{2} \mathrm{O}$ content in the vitreous network and increased temperature, both induce an increase in the dielectric permittivity. Mean while, the progress of $T_{t}$ seems to exhibit different behaviour when we change from glasses to glass ceramics. This could also be explained by the border area separating the glassy and crystallised domains. 


\section{Conclusions}

The regular melting-quench method allowed the isolation of a small vitreous domain within the ternary system $\mathrm{Li}_{2} \mathrm{O}-\mathrm{P}_{2} \mathrm{O}_{5}-\mathrm{Cr}_{2} \mathrm{O}_{3}$ at $1000^{\circ} \mathrm{C}$. Conductivity measurements were realised on glasses and vitreous ceramics isolated within the ternary system $\mathrm{Li}_{2} \mathrm{O}-\mathrm{P}_{2} \mathrm{O}_{5}-\mathrm{Cr}_{2} \mathrm{O}_{3}$. Dielectric permittivity and dielectric loss were measured at a frequency of $10 \mathrm{MHz}$ and in the temperature range 298 to $573 \mathrm{~K}$. An increase in the $\mathrm{Li}_{2} \mathrm{O}$ content in the glass network results at the same time in an increase in $\varepsilon_{r}^{\prime}(\mathrm{T})$ and an increase in $\operatorname{tg} \delta$. These phenomena result from an increasing depolymerisation of the glass network due to increased numbers of non-bridge oxygens because of the progressive breaking of phosphorus network links as the modifier Li2O content increases. Conductivity measurements were realised on glasses and ceramic ceramics isolated within the ternary system $\mathrm{Li}_{2} \mathrm{O}-\mathrm{P}_{2} \mathrm{O}_{5}-\mathrm{Cr}_{2} \mathrm{O}_{3}$. In both glasses and ceramic glasses, the value of $\sigma$ increases as $\mathrm{Li}_{2} \mathrm{O}$ content increases. The increase of $\sigma$ is probably induced by an increase in the number of $\mathrm{Li}^{+}$carriers whose mobility is facilitated by the depolymerisation of the phosphorus network.

Increase in the $\mathrm{Cr}_{2} \mathrm{O}_{3}$ content seems to have caused different behaviour from glasses to vitreous ceramics. The conductivity decreases in the chromium glasses while it increases in glass ceramics due to network defects, which are probably more numerous and in a favorable position for mobile species. On the other hand, an increase in the chromium oxide content induces a decrease dielectric loss and an increase of $T_{t}$ temperature in the glass. Hence we can say that an increase of $\mathrm{Cr}_{2} \mathrm{O}_{3}$ content induces an increase of the rigidity of the glass network. The highest conductivity obtained at $300^{\circ} \mathrm{C}$ was in the order of $2 \times 10^{-3}(\Omega \mathrm{cm})^{-1}$ with an activation energy of 0.45 e.v; however, this remains low compared with that of the crystalline compound $\mathrm{LiAl}_{11} \mathrm{O}_{17}\left(\sigma=10^{-2}(\Omega \mathrm{cm})^{-1}\right)$ at $25^{\circ} \mathrm{C}$. The obtained conductivities are probably responsible for large dielectric losses, which mean that our glasses are currently not suitable for possible application as dielectric condensers.

\section{References}

[1] Zarziky, J. (1982) Les verres et l'état vitreux; Masson Paris.

[2] Van Ass, H. and Stevels, J.M. (1974) Internal Friction of Mixed Alkali Metaphosphate Glasses. Journal of Non-Crystalline Solids, 15, 215.

[3] Stevels, J.M. (1957) The Electrical Properties of Glass. Handbuch der PhysiK, Berlin, 20,350 .

[4] Panier, T., Foultier, M. and Souquet, J.L. (1983) Electrochemical Properties of Phosphate Based Semi-Conductive Glasses. Solid State Ionics, 9-10, 649-654.

[5] Liu, H.S., Chin, T.S. and Yung, S.W. (1997) FTIR and XPS Studies of Low-Melting PbO-ZnO-P2O5 Glasses. Materials Chemistry and Physics, 50, 1.

[6] Liu, H.S. and Chin, T.S. (1997) Low Melting PbO-ZnO- $\mathrm{P}_{2} \mathrm{O}_{5}$ Glasses. Part 2. A Structural Study by Raman Spectroscopy and MAS-NMR. Physics and Chemistry of Glasses, 38, 123.

[7] Aqdim, S. (1990) Identification et Etude Thermique et Electrique des Phases 
Vitreuses des Systèmes Ternaires $\mathrm{Li}_{2} \mathrm{O}-\mathrm{M}_{2} \mathrm{O}_{3}-\mathrm{P}_{2} \mathrm{O}_{5}(\mathrm{M}=\mathrm{Cr}, \mathrm{Fe})$. Diplôme d'Etude Supérieur de $3^{\text {ème }}$ Cycle, Faculté des Science Rabat.

[8] Aqdim, S. and Ouchetto, M. (2013) Elaboration and Structural Investigation of Iron (III) Phosphate Glasses. Advances in Materials Physics and Chemistry, 3, 332-339. https://doi.org/10.4236/ampc.2013.38046

[9] Aqdim, S., Sayouty, El.H. and Elouadi, B. (2008) Structural and Durability Investigation of the Vitreous Part of the System (35-z) $\mathrm{Na}_{2} \mathrm{O}-\mathrm{zFe}_{2} \mathrm{O}_{3}-5 \mathrm{Al}_{2} \mathrm{O}_{3}-60 \mathrm{P}_{2} \mathrm{O}_{5}$. Eurasian Chemico-Technological Journal, 10, 9.

[10] Aqdim, S., Sayouty, El.H., Elouadi, B. and Greneche, J.M. (2012) Chemical Durability and Structural Approach of the Glass Series (40-y) $\mathrm{Na}_{2} \mathrm{O}-\mathrm{yFe} \mathrm{O}_{3}-5 \mathrm{Al}_{2} \mathrm{O}_{3}-55 \mathrm{P}_{2} \mathrm{O}_{5}$. Materials Science and Engineering, 27, Article ID: 012003.

[11] Makhkhas, Y., Aqdim, S. and Sayouty, El.H. (2013) Study of Sodium ChromiumIron-Phosphate Glass by XRD, IR, Chemical Durability and SEM. Journal of Materials Science and Chemical Engineering, 1, 1-6. https://doi.org/10.4236/msce.2013.13001

[12] Beloued, N., Chabbou, Z. and Aqdim, S. (2016) Correlation between Chemical Durability Behaviour and Structural Approach of the Vitreous Part of the System $55 \mathrm{P}_{2} \mathrm{O}_{5}-2 \mathrm{Cr}_{2} \mathrm{O}_{3}-(43-\mathrm{x}) \mathrm{Na}_{2} \mathrm{O}-\mathrm{xPbO}$. Advances in Materials Physics and Chemistry, 6 , 149-156. https://doi.org/10.4236/ampc.2016.66016

[13] Réau, J.-M, Portier, J., Levasseur, A., Villeneuve, G. and Pouchard, M. (1978) Characteristic Properties of New Solid Electrolytes. Materials Research Bulletin, 13, $1415-1423$.

[14] Van Gool, W. (1973) Fast Ion Transport in Solids. North Holland, Amsterdam.

[15] Hagenmuller, P. and Van Gool, W. (1978) Solid Electrolytes. General Principles, Characterization, Materials, Applications. Academic Press, New York.

[16] Choudhary, C.B., Maiti, HS. and Subbarao, E.C. (1980) Solid Electrolytes and Their Applications. Plenum Press.

[17] Rao, R.B., Gopal, N.O. and Veeraiah, N. (2004) Studies on the Influence of $\mathrm{V}_{2} \mathrm{O}_{5}$ on Dielectric Relaxation and Ac Conduction Phenomena of $\mathrm{Li}_{2} \mathrm{O}-\mathrm{MgO}-\mathrm{B}_{2} \mathrm{O}_{3}$ Glass System. Journal of Alloys and Compounds, 368, 25-37.

[18] Ouchetto, M. (1983) Caractérisation et Approche Structural de la région vitreuse du system ternaire $\mathrm{Li}_{2} \mathrm{O}-\mathrm{CdO}-\mathrm{P}_{2} \mathrm{O}_{5}$ Diplôme d'Etude Supérieur de $3^{\text {ème }}$ Cycle, Faculté Des Sciences, Rabat.

[19] Doreau, M., El Anouar, A.A. and Robert, G. (1980) Domainevitreux, structure et conductivité électrique des verres du système $\mathrm{LiCl} / 1 \mathrm{~b} \quad \mathrm{Li}_{2} \mathrm{O} / 1 \mathrm{~b} \quad \mathrm{P}_{2} \mathrm{O}_{5}$. Materials Research Bulletin, 15, 285-294.

[20] Amraoui, N. (1990) Thèse de $3^{\text {ème }}$ cycle, Faculté des Sciences, Rabat.

[21] Arbib, H. (1987) Diplôme d'Etude Supérieure de $3^{\text {ème }}$ Cycle Université, Faculté des Sciences, Rabat.

[22] Imoka, M. (1962) Advances in Glass Technologies. Plenum Press, New York.

[23] Poulain, M., Cohnthansinh, M. and Lucas, J. (1977) Nouveaux verres fluorés. Materials Research Bulletin, 12, 151-156.

[24] Leclaire, A., Ben Moussa, A., Borel, M.M., Grandin, A. and Raveau, B (1988) Two Forms of Sodium Titanium(III) Diphosphate: $\alpha$-NaTiP ${ }_{2} \mathrm{O}_{7}$ Closely Related to $\beta$ Cristobalite and $\beta-\mathrm{NaTiP}_{2} \mathrm{O}_{7}$ Isotypic with $\mathrm{NaFeP}_{2} \mathrm{O}_{7}$. Journal of Solid State Chemistry, 77, 299-305.

[25] Levasseur, A., Brethous, J.C., Reau, J.M. and Hagenmuler, P. (1979) Etude comparee de la conductivite ionique du lithium dans les halogenoborates vitreux. 
Materials Research Bulletin, 14, 912-927.

[26] Zhu, H., Liao, Q., Wang, F., Dai, Y. and Lu, M. (2016) The Effects of Chromiumoxide on the Structure and Properties of Iron Borophosphate Glasses. Journal of NonCrystalline Solids, 437, 48-52.

[27] Durville, F. (1984) Doctorat de 3ème cycle, Université Claude Bernard Lyon I.

[28] Santic, A., Kim, C.W., Day, D.E. and Mogus-Milankovic, A. (2010) Electrical Properties of $\mathrm{Cr}_{2} \mathrm{O}_{3}-\mathrm{Fe}_{2} \mathrm{O}_{3}-\mathrm{P}_{2} \mathrm{O}_{5}$ Glasses. Part II. Journal of Non-Crystalline Solids, 356, 2699-2703.

Submit or recommend next manuscript to SCIRP and we will provide best service for you:

Accepting pre-submission inquiries through Email, Facebook, LinkedIn, Twitter, etc. A wide selection of journals (inclusive of 9 subjects, more than 200 journals) Providing 24-hour high-quality service User-friendly online submission system Fair and swift peer-review system Efficient typesetting and proofreading procedure Display of the result of downloads and visits, as well as the number of cited articles Maximum dissemination of your research work

Submit your manuscript at: http://papersubmission.scirp.org/

Or contact ampc@scirp.org 